\title{
KONDISI SOSIAL-MASYARAKAT PADA KARAKTERISTIK FISIK LINGKUNGAN DALAM MEMPENGARUHI RISIKO LONGSOR DI KARANGSAMBUNG-KEBUMEN (Social-Population Condition on The Physical Environment Characteristics in Influence The Risk of Landslide in Karangsambung Sub Districts-Kebumen)
}

\author{
Puguh Dwi Raharjo* dan Sueno Winduhutomo \\ Balai Informasi dan Konservasi Kebumian Karangsambung, Lembaga Ilmu Pengetahuan Indonesia \\ Jl. Karangsambung km 19 Kebumen, Jawa Tengah 54353. \\ *Penulis korespondensi. Tel: 08156719080. Email: puguh.dwi.raharjo@lipi.go.id.
}

Diterima: 1 April 2015

Disetujui: 12 Juni 2015

\begin{abstract}
Abstrak
Faktor fisik, sosial, ekonomi dan lingkungan memainkan peran kunci kerentanan longsor dalam menentukan risikonya. Kecamatan Karangsambung Kabupaten Kebumen merupakan daerah dengan ragam topografi dan litologi yang memiliki intensitas tanah longsor tinggi. Tujuan dari penelitian ini adalah untuk mengetahui peranan sosial-masyarakat pada setiap desa di Kecamatan Karangsambung dalam mempengaruhi risiko tanah longsor. Pada penelitian ini dilakukan analisis mengenai faktor fisik lingkungan berupa pembuatan peta ancaman longsor. Analytical Hierarchy Process (AHP) digunakan sebagai metode dalam pembuatan peta ancaman yang diolah dengan menggunakan Sistem Informasi Geografis (SIG). Ancaman longsor dihubungkan dengan kondisi sosial-masyarakat dan lingkungan, sehingga terlihat peranannya dalam mengurangi risiko longsor. Hasil yang diperoleh bahwa Desa Totogan, Pujotirto, Wadasmalang, Kaligending, Plumbon, Banioro dan Tlepok memiliki tingkat ancaman longsor yang tinggi. Namun kondisi sosial-masyarakat sangat baik dalam mengatasi dampak dan mitigasi bencana longsor, kecuali pada Banioro. Desa Totogan juga memiliki ancaman longsor akan tetapi kerugian lingkungan apabila terjadi longsor tidak tinggi. Kondisi sosial-masyarakat di setiap desa sangat berpengaruh terhadap risiko longsor pada Kecamatan Karangsambung yang sering terjadi longsor.
\end{abstract}

Kata kunci: kerugian lingkungan, lingkungan fisik, longsor, risiko, sistem informasi geografis, sosial-masyarakat.

\begin{abstract}
Physical, social, economic and environment factors play a role in susceptibility the landslides risk. Subdistricts of Karangsambung - Kebumen is a region with diverse topography and lithology which has a high-intensity landslides. The purpose of this study was to determine the role of socio-community in Karangsambung which influencing the landslides risk. In this study, we analyted every environmental physical factors to give the landslide hazard map. Analytical Hierarchy Process (AHP) is used as a method to processing landslides maps using Geographic Information System (GIS). The landslides hazard associated with the socio-community and the environment, visible role in reducing the landslides risk. The results obtained that the village of Totogan, Pujotirto, Wadasmalang, Kaligending, Plumbon, Banioro and Tlepok have a high-level of landslide hazard. However, the socio-community is very well in overcoming the impact and mitigation of landslides, except Banioro. Totogan also has a high-level landslide hazard but damages the environment in the event of landslides is low. Social conditions is very influential on the landslides risk which often occur in the Karangsambung Sub district.
\end{abstract}

Keywords: financial environment, physical environment, landslide, risk, geographic information system, sociopopulation.

\section{PENDAHULUAN}

Sebuah peristiwa longsor adalah proses alami yang beroperasi di alam tanpa mengganggu masyarakat (Glade, 2006). Risiko tanah longsor tidak hanya dipengaruhi oleh faktor lingkungan fisik saja, namun faktor sosial-masyarakat sangat berpengaruh dalam pengkajian mengenai risiko bencana longsor (Cutter dkk., 2000). Faktor alam hanya menjelaskan mengenai komponen risiko dan termasuk kerentanan dan kapasitas mengatasi (Roberts, 2009) Pengkajian risiko bencana berdasarkan komponen ancaman, kerentanan dan kapasitas (Anonim, 2012). Studi risiko menentukan dampak dari suatu kegiatan atau proses untuk masyarakat (Glade, 2006).

Faktor fisik, sosial, ekonomi, dan lingkungan memainkan peran kunci kerentanan longsor dalam menentukan risikonya (Santha dan Sreedharan, 2010; Song dkk., 2007). Perkiraan luas ekonomi biaya untuk kerusakan longsor dan proaktif langkahlangkah untuk mengatasi sangat diperhitungkan dalam bencana longsor (Glade, 1998). Kerentanan juga berhubungan dengan strategi masyarakat yang 
terkena dampak, dengan kapasitas yang berbeda dalam masyarakat (Glade, 2006). Risiko longsor memperhitungkan reaksi penduduk ketika terjadi peristiwa, hilangnya nyawa menjadi kerugian paling serius (Song dkk., 2007). Unsur-unsur yang berisiko termasuk penduduk, bangunan, infrastruktur, lingkungan dan kegiatan ekonomi yang berada di daerah yang terkena bahaya (Fell dkk., 2005; Cardinali dkk., 2002).

Penelitian mengenai tanah longsor menekankan pada proses alam dan manusia yang berhubungan dengan material geologi yang menyebabkan bencana baik dalam skala lokal maupun global (Timothy, 2008). Fenomena alam ini banyak mengakibatkan kerugian bagi kehidupan manusia dan sumberdaya alam (Intarawichian dan Dasananda, 2010). Pemetaan ancaman longsor pada umumya lebih berdasarkan pada karakteristik fisik lahan, namun dalam pengkajian mengenai resiko bencana longsor ini terdapat aspek sosial dan kelembagaan dimana data yang bersifat administrasi sangat erat kaitannya.

Akurasi peta ancaman longsor sangat tergantung dari jumlah dan kualitas data yang tersedia, skala dan pemilihan metodologi yang tepat dari analisis dan pemodelan (Intarawichian dan Dasananda, 2010). Pemetaan ancaman longsor sangat baik menggunakan pendekatan statistik dalam menganalisis hubungan historis antara faktor pengendali longsor dan distribusi tanah longsor (Guzzetti dkk., 1999). Namun rekaman data-series mengenai kejadian longsor kadang susah di peroleh. Moradi dkk., (2012) menyederhanakan faktor-faktor tersebut yaitu berupa geologi, potensi seismik, kemiringan dan tutupan lahan dianggap sebagai parameter yang mempengaruhi daerah rawan longsor.

Marjanovic (2009) melakukan penelitian berkaitan dengan suksesi multi-kriteria analisis dalam serangkaian peta kerentanan longsor. Pada prinsipnya, menganggap pendekatan pemodelan data raster dan peluang penggabungan data raster dengan melalui Analytical Hierarchy Process (AHP) dan dibantu oleh Sistem Informasi Geografis (SIG). AHP merupakan metode yang dapat digunakan untuk perhitungan domain yang bersifat fisik maupun sosial (Saaty dan Vargas, 2006). AHP dapat membantu dalam proses pengambilan keputusan atau alternatif solusi dari masalah melalui model keputusan hirarkis (Eldrandaly, 2013).

Kawasan Karangsambung merupakan daerah perbukitan dengan topografi dan litologi yang berbeda-beda. Setiap kompleks litologi terdiri jenis batuan yang berbeda dan bervariasi dalam kekuatan dari untuk terjadinya longsor (Cardinali dkk., 2002). Kejadian tanah longsor pada kawasan ini hampir terjadi setiap tahunnya pada musim penghujan. Kondisi sosial-masyarakat pada setiap desa memiliki kondisi yang berbeda, sehingga menjadikan desa dengan ancaman longsor tinggi memiliki risiko longsor yang rendah. Tujuan dari penelitian ini adalah untuk mengetahui peranan sosial-masyarakat pada setiap desa di Kecamatan Karangsambung dalam mempengaruhi risiko tanah longsor. Dengan demikian selanjutnya akan dapat dilakukan pengurangan risiko bencana dengan pada daerah dengan ancaman longsor tinggi di Kecamatan Karangsambung.

\section{METODE PENELITIAN}

\section{Waktu dan Lokasi}

Penelitian ini dilakukan pada bulan Mei Tahun 2014. Penelitian ini berlokasi di Kecamatan Karangsambung Kabupaten Kebumen, Propinsi Jawa Tengah. Lokasi ini berada pada Kawasan Cagar Alam Geologi Karangsambung (Gambar 1). Bahan yang digunakan dalam penelitian ini meliputi citra Landsat 8 perekaman 24 juni 2013 (Anonim, 2013); Peta RBI skala 1:25000 (Anonim, 2001); Peta Geologi skala 1:100000 (Asikin dkk., 1992); dan data statistik Kecamatan Karangsambung dalam angka (Anonim, 2014); dan data fisik tanah (sifat fisik, geser langsung, kuat tekan, plastisitas). Alat yang digunakan dalam penelitian ini meliputi, antara lain yaitu GPS, kompas dan palu geologi, bor tanah dan pipa 2 in, kamera, peta satuan unit, perangkat lunak dan perangkat keras komputer.

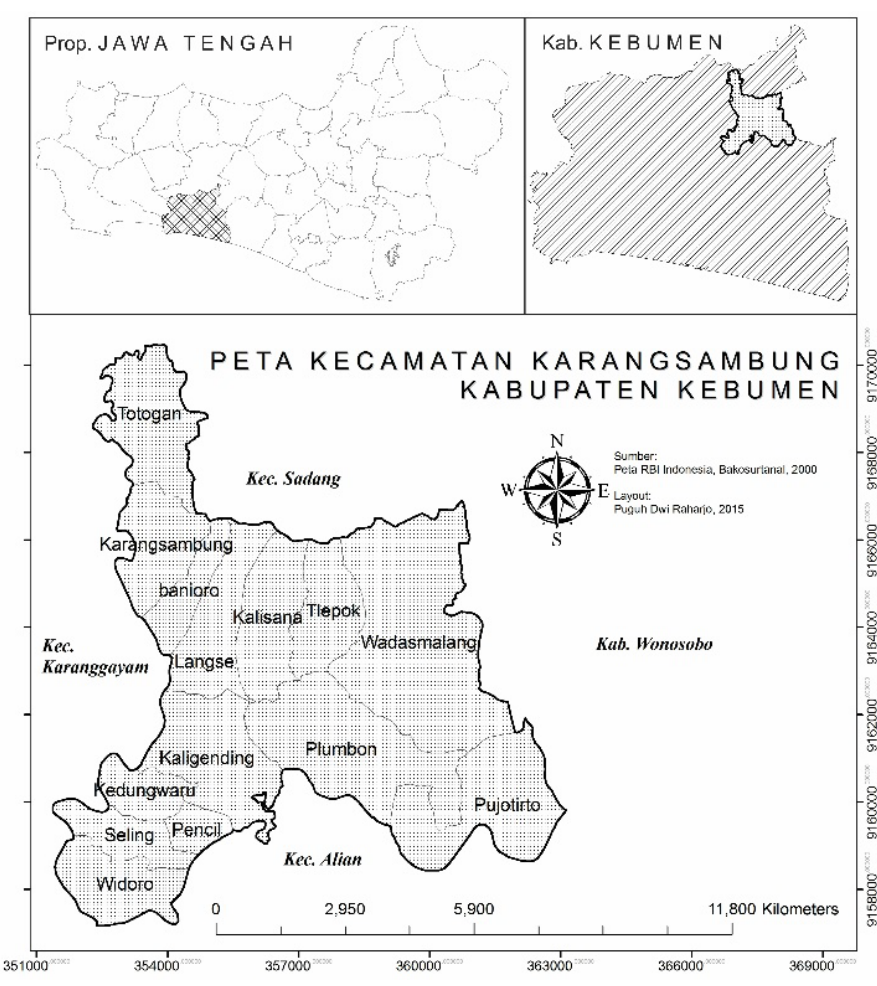

Gambar 1. Lokasi penelitian. 


\section{Faktor Fisik}

Lingkungan fisik merupakan faktor pengontrol terjadinya longsor. Determinasi dari berbagai kriteria yang mengakibatkan terjadinya kemudahan pada wilayah tersebut untuk longsor, yaitu: geologi, karakteristik tanah (plastisitas tanah, geser langsung, dan kuat tekan), kemiringan lereng, dan penggunaan lahan. Bentuklahan serta kemiringan lereng sangat penting dalam pembeda satuan peta tanah karena merupakan suatu fase dalam taksonomi tanah (Anonim, 2004). Data mengenai karakteristik tanah merupakan data primer yang memerlukan sampel dan analisis laboratorium. Satuan yang digunakan dalam zonasi karakteritik lahan ini berdasarkan bentuklahan daerah penelitian. Tiap bentuklahan dilakukan pengambilan sampel dan analisis laboratorium guna mengetahui kemudahan untuk terjadinya longsor.

Semua kriteria yang dianggap relevan untuk keputusan dibandingkan terhadap satu sama lain dalam pairwise comparison yang merupakan ukuran untuk mengekspresikan preferensi relatif antara kriteria. Nilai numerik mengungkapkan penilaian kepentingan relatif (atau preferensi) dari satu kriteria terhadap yang lain harus ditugaskan untuk setiap kriteria, seperti Gambar 2.

Pada penelitian ini pendekatan yang digunakan adalah pemodelan data raster dan peluang penggabungan data raster dengan melalui AHP dan dibantu oleh SIG. Data penginderaan jauh digunakan sebagai bahan data primer dalam ekstraksi informasi permukaan, seperti penutup lahan dan kerapatan vegetasi, kemiringan lereng, dan unit medan. AHP yang merupakan salah satu metode dalam pengambilan keputusan (Saaty, 1970 dalam Saaty dan Vargas, 2006) untuk menguraikan masalah multi kriteria yang kompleks menjadi suatu hirarki. Metode ini mendasarkan pada pairwise comparison (matriks perbandingan berpasangan) dalam membentuk seluruh prioritas untuk mengetahui ranking dari alternatif yang terdiri dari tujuan, kriteria, dan alternatif. Nilai numerik memberikan penilaian kepentingan relatif (preferensi) dari satu faktor terhadap lainnya pada setiap faktor. Untuk menghitung matrik pairwise comparison setiap kriteria/faktor dan bobot nilai adalah $\mathrm{a}_{1}, \mathrm{a}_{2}, \ldots, \mathrm{a}_{\mathrm{n}}$ dan $\mathrm{w}_{1}, \mathrm{w}_{2}, \ldots, \mathrm{w}_{\mathrm{n}}$, dengan formula sebagai berikut:

$$
\begin{aligned}
& a_{i j}=\frac{a_{i j}}{\sum_{i=1}^{n} a_{i j}} \quad i, j=1,2, \ldots . ., n \\
& w_{i}=\left(\frac{1}{n}\right) \sum_{j=1}^{n} a_{i j}^{\prime} \quad i=1,2, \ldots ., n
\end{aligned}
$$

Masing-masing kriteria diuji matrik pairwise comparison, serta menghitung Consistency Index (CI) untuk menentukan Consistency Ratio (CR) kurang atau sama dengan 10\%) yang digunakan untuk mengetahui ketepatan keputusan.

$$
\text { CI }=\lambda \max -n / n-1
$$

Nilai Random Index (RI) ditentukan pada ketetapan, dengan $\mathrm{n}$ adalah jumlah matrik (Saaty dan Vargas, 2006), seperti Tabel 1. CR merupakan indeks angka tunggal untuk mengetahui konsistensi dari matrik pairwise comparison, sehingga dilakukan perbandingan antara CI dengan RI.

$$
\mathrm{CR}=\mathrm{CI} / \mathrm{RI}
$$

Hasil dari pemetaan longsor ini berupa peta ancaman kerawan longsor yang berdasarkan karakteristik fisik lingkungan. Parameter fisik ini merupakan faktor pengontrol dalam menjadikan tingkatan kemudahan terjadinya longsor. Peranan faktor sosial, ekonomi dan kependudukan tidak diperlukan dalam menentukan daerah yang memiliki ancaman kerawanan longsor.

\section{Faktor Sosial-Masyarakat}

Pada keadaan normal (prabencana) pendidikan lingkungan perlu difokuskan pada tindakan-tindakan strategis, masyarakat perlu mendapatkan pemahaman dan pengetahuan tentang kondisi lingkungan dan sumberdaya alam yang makin kritis dan tengah berada dalam krisis (Suharko, 2014). Bencana longsor akan berdampak apabila terjadi kerugian baik dari sisi jiwa maupun ekonomi. Penilaian risiko longsor dari kerugian jiwa diperlukan data, seperti kepadatan penduduk, penduduk miskin, penduduk cacat, usia balita, dan usia lansia (indeks penduduk terpapar). Risiko longsor tinggi pada faktor sosial masyarakat ini terjadi ketika kepadatan penduduk, rasio penduduk cacat, rasio balita, dan rasio lansia tinggi. Hal ini dilihat dari kemampuan masyarakat dalam menyelamatkan diri ketika terjadinya bencana.

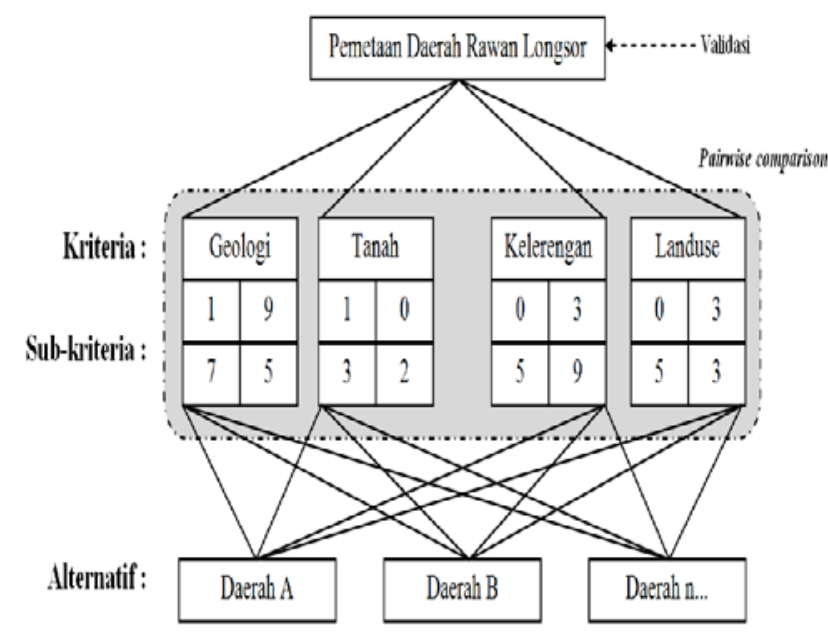

Gambar 2. Proses pemetaan ancaman rawan longsor dengan metode AHP. 
Tabel 1. Nilai ketetapan random index.

\begin{tabular}{ccccccccccc}
\hline $\mathbf{n}$ & 1 & 2 & 3 & 4 & 5 & 6 & 7 & 8 & 9 & 10 \\
\hline $\mathbf{R I}$ & 0,00 & 0,00 & 0,58 & 0,90 & 1,12 & 1,14 & 1,32 & 1,41 & 1,46 & 1,49 \\
\hline
\end{tabular}

Sumber : Hasil analisis.

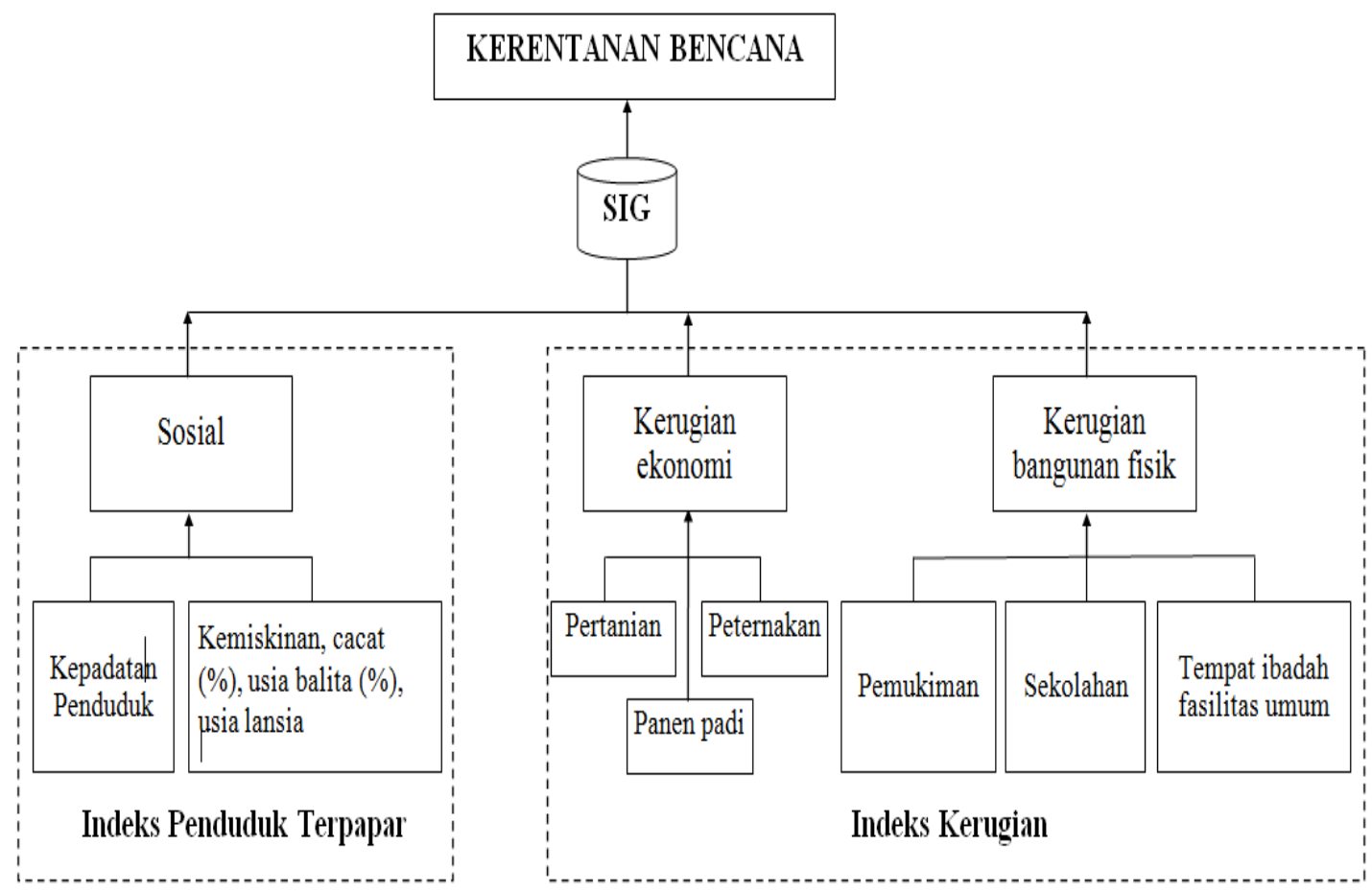

Gambar 3. Proses indeks kerentanan bencana longsor.

Faktor sosial-masyarakat yang juga mempengaruhi risiko longsor adalah keberadaan tenaga kesehatan, tenaga pendidik, dan tenaga limnas. Faktor ini merupakan indeks kapasitas bencana, semakin banyak keberadaan tenaga kesehatan, tenaga pendidik, dan tenaga limnas maka risiko bencana semakin kecil. Penilaian indeks penduduk terpapar dan indeks kapasitas bencana didasarkan pada rasio data dalam setiap desa.

\section{Faktor Lingkungan}

Bencana longsor dapat menyebabkan kerusakan tatanan bentang lahan, sumber daya alam dan lingkungan (Lihawa dkk., 2014). Bencana tanah longsor selain mengakibatkan kerugian jiwa juga mengakibatkan kerugian material. Kerugian ini dilihat dari sisi infrastruktur, bangunan pemukiman, dan kerugian pertanian. Desa dengan peruntukan pertanian produktif, dengan panen bisa 2 kali setahun, serta desa dengan ruta usaha pertanian memiliki nilai dengan tingkat kerugian ekonomi yang tinggi. Seperti halnya desa dengan jumlah bangunan pemukiman, fasilitas umum dan ibadah, serta jumlah sekolah yang tinggi menjadikan faktor lingkungan mengalami kerugian yang tinggi apabila terjadi bencana longsor. Pengkelasan nilai berdasarkan data per-desa di Kecamatan Karangsambung.

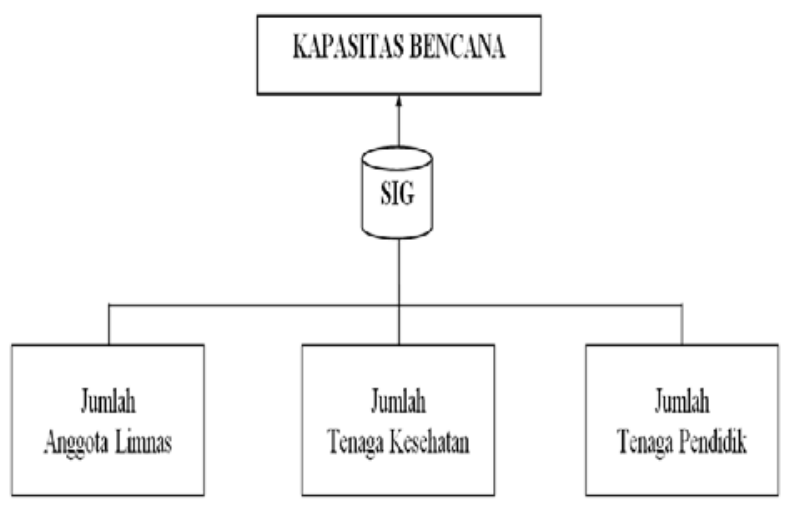

Gambar 4. Proses indeks kapasitas bencana longsor.

\section{Indeks Kerentanan Longsor}

Data indeks penduduk terpapar dan kerugian faktor lingkungan merupakan indeks kerentanan longsor. Data kecamatan dalam angka (Anonim, 2014) diolah untuk mengetahui pengkelasan pada setiap jenis data. Data yang dikelaskan berdasarkan nilai maksimum, minimum, dan nilai antara pada setiap jenis data. Gambar 3 merupakan proses dalam pemetaan Indeks Kerentanan Bencana Longsor.

Indeks kerentanan diperoleh setelah peta ancaman untuk bencana longsor selesai disusun. Persamaan untuk menghitung indeks kerentanan 
ancaman tanah longsor disajikan pada persamaan 5 (Anonim, 2012 dengan modifikasi).

Indeks Kerentanan $=$

$$
(0,5 . K S)+(0,25 . K E)+(0,25 . K F)
$$

KS: $\quad$ skor kerentanan sosial

KE: $\quad$ skor kerentanan ekonomi

KF: $\quad$ skor kerentanan fisik

Nilai bobot yang diberikan pada masing-masing kriteria berdasarkan tingkat korban apabila terjadi bencana longsor dan juga kemampuan penduduk masyarakat dalam melakukan mitigasi yang bersifat individual. Interval kelas terendah sampai tertinggi diambil dari nilai kelas yang ada di Kecamatan Karangsambung.

\section{Indeks Kapasitas Longsor}

Indeks Kapasitas (Gambar 4) difokuskan pada beberapa pelaku penanggulangan bencana pada suatu daerah. Indikator yang digunakan untuk peta kapasitas pada penelitian ini adalah pendidikan kebencanaan dan kesiapsiagaan terhadap kejadian bencana longsor. Perolehan data pendidikan kebencanaan didasarkan pada jumlah perangkat desa dan juga jumlah guru yang ada pada kawasan ini, dimana semakin banyak jumlahnya maka penyebaran informasi mengenai mitigasi semakin baik.

Kesiapsiagaan terhadap kejadian bencana/pendidikan kebencanaan longsor ini didasarkan pada jumlah tenaga kesehatan, jumlah tenaga pendidik, dan jumlah anggota limnas. Persamaan indeks kapastitas pada penelitian ini disajikan pada persamaan 6 (Anonim, 2012 dengan modifikasi).

Indeks Kapasitas $=$

$$
(0,4 . \mathrm{TK})+(0,30 . \mathrm{PB})+(0,30 . \mathrm{ST})
$$

TK: $\quad$ skor tenaga kesehatan

PB: skor pendidikan kebencanaan

SL: skor tenaga limnas

\section{Pengkajian Risiko Bencana Longsor}

Risiko bencana merupakan penilaian hasil dari ancaman/kerawanan longsor yang merupakan aspek fisik dengan hasil dari kerentanan dan kapasitas yang merupakan aspek sosial-masyarakat dan lingkungan.

Secara terdistribusi masing-masing fungsi tersebut dapat dengan mudah diproses dengan menggunakan SIG yang dituangkan dalam bentuk peta. Persamaan dalam menentukan risiko bencana (Anonim, 2012) adalah mengikuti persamaan 7. Risiko $=$

$$
\sqrt[3]{ }(\text { bahaya . kerentanan . \{1- Capacity }\})
$$

Pemetaan resiko bencana terutama untuk kejadian longsor dipertimbangkan beberapa faktor, yaitu: kemungkinan longsor terjadi pada lokasi tertentu, dampak kerugian dari kejadian longsor, dan juga kemampuan daerah tersebut untuk melakukan rehabilitasi akibat bencana longsor. Penggabungan dari distribusi ancaman kerawanan longsor dan distribusi kerentanan dan kapasitas akan terlihat dimana pengaruh kondisi sosial-masyarakat dan lingkungan sangat mempengaruhi terhadap aspek fisik.

\section{HASIL DAN PEMBAHASAN}

Aspek fisik yang mempengaruhi longsor digunakan sebagai dasar untuk pemetaan ancaman kerawanan longsor. Perhitungan kriteria yang mempengaruhi ancaman bencana longsor, bobot untuk kriteria kemiringan lereng paling tinggi dengan nilai sekitar 57,75\%. Kriteria geologi juga dianggap memiliki pengaruh yang tinggi setelah kriteria kemiringan pada perhitungan diatas yaitu sekitar 20,94\%. Kriteria geologi ini bersifat lebih pada permukaan, hal ini mengandung arti bahwa kriteria geologi ini merupakan dasar dalam melihat kestabilan permukaan, kekuatan permukaan, dan kemudahan permukaan dalam menjadikan tanah untuk bergerak ketika adanya suatu tenaga yang mengenainya. Kriteria tanah dalam penelitian ini merupakan suatu karakteristik tanah dalam satuan/unit lahan dimana karakteristik sifat dan cirinya adalah sama. Generalisasi dalam satuan lahan ini merupakan unit yang berskala sehingga setiap unit sudah mewakili karakteristiknya. Karakteristik tanah dengan sifat sebagai Factor of Safety (Fs) ini memiliki nilai pengaruh sekitar 13,31\%. Kriteria penggunaan lahan memiliki pengaruh dalam mengontrol potensi longsor paling rendah, yaitu hanya sekitar 6,00\%. Penilaian ini lebih pada suatu kondisional pada daerah penelitian mengingat kejadian longsor lebih banyak terjadi di berbagai penggunaan lahan yang bervegetasi.

Kemiringan lereng pada penelitian ini (Tabel 2) terdapat 6 (enam) kelas/sub kriteria, yang dibagi per $15^{\circ}$. Pada perhitungan dengan menggunakan metode AHP rentang kemiringan 75 - $90^{\circ}$ merupakan sub kriteria yang memiliki pengaruh untuk terjadi longsor paling tinggi yaitu sekitar 41,0\%, yang berarti bahwa kemiringan kelas ini mutlak dalam mempengaruhi terjadinya longsor apabila dibandingkan dengan kelas $0-15^{\circ}$ yang hanya memiliki pengaruh untuk terjadinya longsor sekitar 2,0\%. Perhitungan pairwaise comparasion untuk kriteria kemiringan lereng pada metode AHP ini memenuhi syarat perbandingan konsistensi 
(consistency ratio) kurang dari 0,1 yaitu sebesar 0, 079.

Pada sub kriteria geologi Formasi KTI, Km, Kose memiliki nilai yang paling tinggi, sub kriteria geologi Formasi Teok, Tomt, Tmp lebih mudah terjadi longsor apabila dibandingakan dengan sub kriteria pada Formasi Tmw, KTs. Sub kriteria geologi Formasi Tmd, Kobe, Tmpb, Tmph memiliki nilai yang paling rendah pada permukaan lahan yang terdapat kebatuan permukaan. Aluvial (Qa) jelas sangat tidak mungkin terjadi longsor mengingat lokasinya pada topografi rendah dan kemiringan yang datar, kecuali hanya terjadi longsor di tepi sungai. Perhitungan pairwaise comparasion untuk kriteria geologi pada metode AHP (Tabel 3) ini memenuhi syarat perbandingan konsistensi kurang dari 0,1 yaitu sebesar 0,065.

Pengambilan sampel tanah dilakukan secara undisturb pada setiap bentuklahan yang diasumsikan sebagai satuan pemetaannya (Tabel 4). Data-data yang dilakukan analisis laboratorium meliputi kadar air, berat jenis, batas atterberg/cair/plastis, ukuran butir, permeabilitas, triaksial pada 14 unit medan. Pada perhitungan factor of safety (Fs) sampel KRS S1/1 (Blok Sesar Terkikis Sangat Ringan) sebesar 0,812; sampel KRS S1/2 (Blok Sesar Terkikis Ringan) sebesar $\quad 0,742$; sampel KRS S5/1 (Perbukitan Antiklinal Terkikis Ringan) sebesar 0,846; sampel KRS F1 (Dataran Aluvial) sebesar 0,781; sampel KRS D7 (Lereng Kaki) sebesar 0,729; sampel KRS D8 (Pedimen) sebesar 0,597; sampel KRS D1/1 (Perbukitan Terkikis Sangat Ringan) sebesar 0,725; sampel KRS D1/3 (Perbukitan Terkikis Sedang) sebesar 0,778; sampel KRS D1/4 (Perbukitan Terkikis Berat) sebesar 0,880; sampel KRS S1/3 Blok Sesar Terkikis Sedang) sebesar 0,596; sampel KRS S16/3 (Lembah Antiklinal Terkikis Sedang) sebesar 0,710; dan sampel KRS S16/4 (Lembah Antiklinal Terkikis Berat) sebesar 0,832. Klasifikasi bentuklahan menggunakan berdasarkan Bakosurtanal-Fakultas Geografi UGM (Suharsono, 1988) pada skala 1:50.000 dengan perubahan.

Tabel 2. Pairwise comparison sub-kriteria kemiringan lereng di Kecamatan Karangsambung.

\begin{tabular}{llccc}
\hline $\begin{array}{l}\text { Sub kriteria } \\
\text { Lereng }\left(^{\circ}\right)\end{array}$ & $\begin{array}{l}\text { Pengukuran } \\
\text { konsistensi }\end{array}$ & Indeks konsistensi & Rasio indeks & Konsistensi rasio \\
\hline $75-90$ & 6,84 & & & \\
$60-75$ & 6,87 & & & \\
$45-60$ & 6,54 & 0,09 & 1,14 & 0,079 \\
$30-45$ & 6,21 & & & (Konsisten) \\
$15-30$ & 6,07 & & \\
$0-15$ & 6,19 & & \\
\hline
\end{tabular}

Sumber : Hasil analisis.

Tabel 3. Pairwise comparison sub-kriteria litologi di Kecamatan Karangsambung.

\begin{tabular}{|c|c|c|c|c|}
\hline Sub kriteria & $\begin{array}{c}\text { Pengukuran } \\
\text { konsistensi }\end{array}$ & $\begin{array}{c}\text { Indeks } \\
\text { konsistensi }\end{array}$ & $\begin{array}{l}\text { Rasio } \\
\text { indeks }\end{array}$ & Konsistensi rasio \\
\hline KTI, Km, Kose & 5,5 & \multirow{5}{*}{0,072} & \multirow{5}{*}{1,12} & \multirow{5}{*}{$\begin{array}{c}0,065 \\
\text { (Konsisten) }\end{array}$} \\
\hline Teok, Tomt, Tmp, & 5,4 & & & \\
\hline Tmw, KTs & 5,3 & & & \\
\hline Tmd, Kobe, Tmpb, Tmph & 5,1 & & & \\
\hline Tekl, Qa & 5,2 & & & \\
\hline
\end{tabular}

Sumber : Hasil analisis.

Tabel 4. Hasil analisis sampel tanah pada setiap unit medan

\begin{tabular}{|c|c|c|c|c|c|c|}
\hline Kode Sampel & $\begin{array}{l}\text { Kohesi efektif (c') } \\
\qquad\left(\mathrm{kg} / \mathrm{cm}^{2}\right)\end{array}$ & $\begin{array}{l}\text { Sudut geser dalam } \\
\text { efektif }\left(\mathrm{j}^{\prime}\right)\left({ }^{\circ}\right)\end{array}$ & $\begin{array}{l}\text { Berat isi } \\
\text { (g/cc) }\end{array}$ & $\begin{array}{l}\text { Sudut } \\
\text { lereng }\end{array}$ & Berat asli (g) & Nilai Fs \\
\hline KRS S1/1 & 0,051 & 20,97 & 1,69 & 50 & 114,05 & 0,812 \\
\hline KRS S1/2 & 0,021 & 23,12 & 1,79 & 54 & 121,00 & 0,742 \\
\hline KRS S5/1 & 0,043 & 22,89 & 1,76 & 48 & 118,63 & 0,846 \\
\hline KRS F1 & 0,338 & 10,88 & 1,65 & 52 & 131,49 & 0,781 \\
\hline KRS D7 & 0,417 & 11,93 & 1,64 & 55 & 110,50 & 0,729 \\
\hline KRS D8 & 0,440 & 10,25 & 1,80 & 62 & 121,36 & 0,597 \\
\hline KRS D1/1 & 0,011 & 24,58 & 1,61 & 55 & 120,63 & 0,725 \\
\hline KRS D1/3 & 0,009 & 25,15 & 1,85 & 52 & 124,32 & 0,778 \\
\hline KRS D1/4 & 0,308 & 10,34 & 1,74 & 46 & 117,40 & 0,880 \\
\hline KRS S1/3 & 0,286 & 9,65 & 1,78 & 62 & 119,76 & 0,596 \\
\hline KRS S16/3 & 0,338 & 13,13 & 1,65 & 56 & 111,37 & 0,710 \\
\hline KRS S16/4 & 0,338 & 10,88 & 1,65 & 49 & 111,12 & 0,832 \\
\hline
\end{tabular}

Sumber : Hasil analisis. 
Tabel 5. Pairwise comparison sub-kriteria karakteristik tanah di Kecamatan Karangsambung

\begin{tabular}{|c|c|c|c|c|}
\hline Sub kriteria & Pengukuran konsistensi & Indeks konsistensi & Rasio indeks & Konsistensi rasio \\
\hline D8 & 14,81 & \multirow{13}{*}{0,048} & \multirow{13}{*}{1,57} & \multirow{13}{*}{$\begin{array}{c}0,030 \\
\text { (Konsisten) }\end{array}$} \\
\hline $\mathrm{S} 1 / 3$ & 14,94 & & & \\
\hline $\mathrm{S} 1 / 4$ & 14,94 & & & \\
\hline $\mathrm{S} 16 / 3$ & 14,96 & & & \\
\hline $\mathrm{D} 1 / 1$ & 14,80 & & & \\
\hline D7 & 14,83 & & & \\
\hline $\mathrm{S} 1 / 2$ & 14,64 & & & \\
\hline $\mathrm{D} 1 / 3$ & 14,64 & & & \\
\hline F1 & 14,36 & & & \\
\hline $\mathrm{S} 1 / 1$ & 14,27 & & & \\
\hline $\mathrm{S} 16 / 4$ & 14,17 & & & \\
\hline $\mathrm{S} 5 / 1$ & 14,15 & & & \\
\hline D1/4 & 14,24 & & & \\
\hline
\end{tabular}

Sumber : Hasil analisis.

Tabel 6. Pairwise comparison sub-kriteria penggunaan lahan di Kecamatan Karangsambung.

\begin{tabular}{lcccc}
\hline Sub kriteria & Pengukuran konsistensi & Indeks konsistensi & Rasio indeks & Konsistensi rasio \\
\hline Lahan terbangun & 9,22 & & & \\
Hutan & 9,64 & & & \\
Kebun campur & 9,64 & & & \\
Tegalan & 9,79 & 0,017 & \\
Semak-belukar & 9,56 & & \\
Sawah & 8,59 & & \\
Lahan terbuka & 8,40 & & \\
Tubuh air & 8,26 & & \\
\hline
\end{tabular}

Sumber : Hasil analisis.

Nilai consitency index (CI) dan index random (RI) pada sub-kriteria karakteristik tanah (Tabel 5) yang diperoleh sebesar 0,048 dan 1,57, nilai tersebut menghasilkan consistency ratio (CR) 0,030. Subkriteria karakteristik tanah ini pada metode AHP dinilai sangat baik karena consistency ratio kurang dari $10 \%$.

Pada sub-kriteria penggunaan lahan mendasarkan pada kondisi di lapangan dengan mempertimbangkan beban pada penggunaan lahan serta kemampuannya dalam menyimpan / menyalurkan air dalam tanah yang dapat mengakibatkan kejenuhan tanah. Nilai CI dan RI pada sub-kriteria penggunaan lahan yang diperoleh sebesar 0,017 dan 1,46, nilai tersebut menghasilkan CR sebesar 0,012. Sub-kriteria penggunaan lahan ini pada metode AHP dinilai sangat baik karena consistency ratio kurang dari $10 \%$, sehingga untuk perhitungan pairwise comparison (Tabel 6) dapat diterima.

Pada perhitungan AHP tiap kriteria untuk faktor pengontrol terjadinya longsor (kemiringan lereng, litologi, karakteristik tanah dan penggunaan lahan) diperoleh nilai CR yang masih dalam ambang yang diperbolehkan (kurang dari 10\%). Keempat kriteria tersebut merupakan model peta ancaman longsor di Kecamatan Karangsambung (Gambar 5).

Pada peta ancaman longsor terlihat bahwa ancaman tinggi memiliki penyebaran paling banyak pada Formasi Waturanda, yaitu pada kemiringan

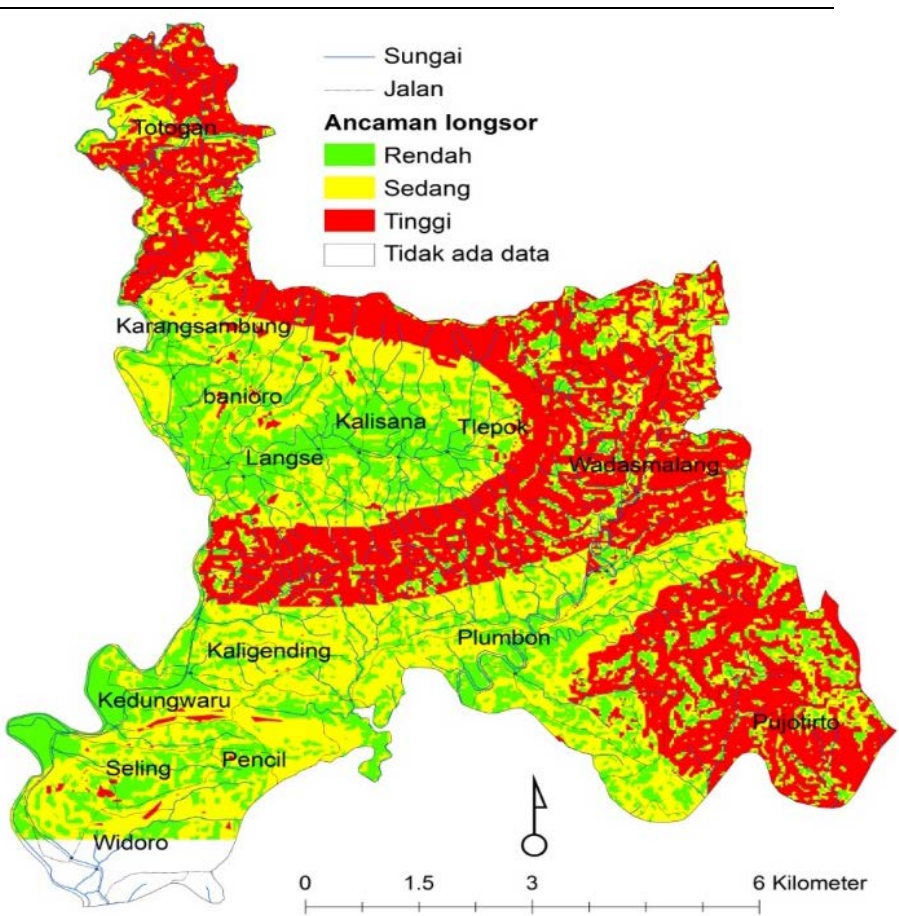

Gambar 5. Peta ancaman longsor di Kecamatan Karangsambung.

tinggi di sekitar igir baik pada sisi dalam maupun luar dari Lembah Antiklin. Desa Totogan juga memiliki potensi ancaman longsor yang tinggi. Secara geologi daerah tersebut merupakan Zona Melange yang secara genesis litologi merupakan percampuran dari berbagai macam batuan. Selain itu 
pada daerah ini juga merupakan daerah perbukitan dengan kemiringan yang terjal. Ancaman longsor yang tinggi juga terdapat di Desa Pujotirto, Wadasmalang, Kaligending, Plumbon, Banioro, dan Tlepok yang berada pada perbukitan dengan lereng curam.

Aspek fisik merupakan faktor yang dominan dalam menentukan dalam zonasi peta ancaman longsor. Ancaman longsor tinggi di Kecamatan Karangsambung ini terjadi rata-rata di kemiringan lereng yang lebih dari $40^{\circ}$. Parameter geologi yang banyak terjadi longsoran terdapat di formasi-formasi Batugamping Terumbu, Karangsambung, Totogan, Komplek Lok Ulo, Penosogan, Sekis dan Filit, Serpentinit, dan Batuan terbreksikan.

Perhitungan Fs pada analisa tanah, sampel tanah pada satuan bentuklahan blok seser dan perbukitan merupakan wilayah yang sangat rawan terhadap longsor. Penggunaan lahan lahan terbangun, hutan dan kebun campur merupakan jenis yang mudah dalam mengontrol tanah longsor.

Kondisi sosial-masyarakat berupa indeks penduduk terpapar di Kecamatan Karangsambung (Tabel 7) untuk kepadatan penduduk Desa Widoro, Kedungwaru, Banioro dan Karangsambung memiliki kerentanan terhadap penduduk yang tinggi yaitu dengan nilai di atas $6,67 \%$. Faktor masyarakat dengan taraf hidup pra sejahtera tinggi berada pada Desa Pencil, nilai sedang meliputi Desa Plumbon, Tlepok, dan Kalisana. Desa-desa lainnya di Kecamatan Karangsambung berada di tingkat pra sejahtera rendah. Faktor rasio untuk orang cacat Desa Banioro memiliki tingkat paling tinggi, yaitu dari 1764 jiwa terdapat terdapat 28 orang yang mengalami cacat. Tingkat rasio penduduk balita yang memiliki kerentanan tinggi berada di Desa Pujotirto dan Karangsambung, sedangkan rasio penduduk lansia yang memiliki kerentanan tinggi berada di Desa Seling dan Pencil.

Tabel 7. Indeks penduduk terpapar Kecamatan Karangsambung.

\begin{tabular}{|c|c|c|c|c|c|c|c|c|c|c|}
\hline \multirow[t]{2}{*}{ Desa } & \multicolumn{2}{|c|}{$\begin{array}{l}\text { Kepadatan } \\
\text { penduduk }\end{array}$} & \multicolumn{2}{|c|}{$\begin{array}{l}\text { Rasio penduduk } \\
\text { miskin }\end{array}$} & \multicolumn{2}{|c|}{$\begin{array}{l}\text { Rasio penduduk } \\
\text { cacat }\end{array}$} & \multicolumn{2}{|c|}{ Rasio balita } & \multicolumn{2}{|c|}{ Rasio lansia } \\
\hline & Nilai & Skor & Nilai & Skor & Nilai & Skor & Nilai & Skor & Nilai & Skor \\
\hline Widoro & 0,81 & 3 & 8,85 & 1 & 0,71 & 2 & 9,46 & 2 & 2,86 & 1 \\
\hline Seling & 0,49 & 2 & 9,62 & 1 & 0,89 & 2 & 7,19 & 1 & 4,28 & 3 \\
\hline Kedungwaru & 0,68 & 3 & 2,46 & 1 & 0,91 & 2 & 8,30 & 1 & 2,96 & 1 \\
\hline Pencil & 0,31 & 1 & 40,86 & 3 & 0,81 & 2 & 6,99 & 1 & 4,57 & 3 \\
\hline Kaligending & 0,58 & 2 & 10,76 & 1 & 0,39 & 2 & 9,46 & 2 & 3,31 & 2 \\
\hline Plumbon & 0,52 & 2 & 12,70 & 2 & 0,52 & 2 & 8,89 & 2 & 2,89 & 2 \\
\hline Pujotirto & 0,58 & 2 & 10,35 & 1 & 0,45 & 1 & 11,28 & 3 & 2,69 & 1 \\
\hline Wadasmalang & 0,36 & 2 & 11,92 & 1 & 0,47 & 1 & 9,64 & 2 & 2,68 & 1 \\
\hline Tlepok & 0,36 & 2 & 12,93 & 2 & 0,61 & 2 & 8,65 & 2 & 3,52 & 2 \\
\hline Kalisana & 0,52 & 2 & 13,47 & 2 & 0,48 & 1 & 8,43 & 2 & 2,52 & 1 \\
\hline Langse & 0,59 & 2 & 11,76 & 1 & 0,45 & 1 & 8,36 & 1 & 3,44 & 2 \\
\hline Banioro & 0,81 & 3 & 9,64 & 1 & 1,59 & 3 & 8,45 & 2 & 2,66 & 1 \\
\hline Karangsambung & 0,97 & 3 & 10,29 & 1 & 0,57 & 2 & 9,98 & 3 & 2,26 & 1 \\
\hline Totogan & 0,30 & 1 & 11,06 & 1 & 0,80 & 2 & 9,34 & 2 & 2,83 & 1 \\
\hline
\end{tabular}

Sumber : Hasil analisis. Keterangan : ${ }^{1)}$ rentan rendah, ${ }^{2)}$ rentan sedang, dan ${ }^{3)}$ rentan tinggi.

Tabel 8. Indeks kerugian bencana longsor di Kecamatan Karangsambung.

\begin{tabular}{llllllll}
\hline \multicolumn{1}{c}{ Desa } & $\begin{array}{c}\text { Kepadatan } \\
\text { penduduk }\end{array}$ & $\begin{array}{c}\text { Keluarga } \\
\text { miskin }\end{array}$ & $\begin{array}{c}\text { Orang } \\
\text { cacat }\end{array}$ & $\begin{array}{c}\text { Penduduk } \\
\text { balita }\end{array}$ & $\begin{array}{c}\text { Penduduk } \\
\text { Lansia }\end{array}$ & $\begin{array}{c}\text { Indeks } \\
\text { kerentanan }\end{array}$ & Kriteria \\
\hline Widoro & 1,20 & 0,15 & 0,30 & 0,30 & 0,15 & 2,10 & Tinggi \\
Seling & 0,80 & 0,15 & 0,30 & 0,15 & 0,45 & 1,85 & Sedang \\
Kedungwaru & 1,20 & 0,15 & 0,30 & 0,15 & 0,15 & 1,95 & Tinggi \\
Pencil & 0,40 & 0,45 & 0,30 & 0,15 & 0,45 & 1,75 & Sedang \\
Kaligending & 0,80 & 0,15 & 0,30 & 0,30 & 0,30 & 1,85 & Sedang \\
Plumbon & 0,80 & 0,30 & 0,30 & 0,30 & 0,30 & 2,00 & Sedang \\
Pujotirto & 0,80 & 0,15 & 0,15 & 0,45 & 0,15 & 1,70 & Sedang \\
Wadasmalang & 0,80 & 0,15 & 0,15 & 0,30 & 0,15 & 1,55 & Sedang \\
Tlepok & 0,80 & 0,30 & 0,30 & 0,30 & 0,30 & 2,00 & Tinggi \\
Kalisana & 0,80 & 0,30 & 0,15 & 0,30 & 0,15 & 1,70 & Sedang \\
Langse & 0,80 & 0,15 & 0,15 & 0,15 & 0,30 & 1,55 & Sedang \\
Banioro & 1,20 & 0,15 & 0,45 & 0,30 & 0,15 & 2,25 & Tinggi \\
Karangsambung & 1,20 & 0,15 & 0,15 & 0,45 & 0,15 & 2,10 & Tinggi \\
Totogan & 0,40 & 0,15 & 0,15 & 0,30 & 0,15 & 1,15 & Rendah \\
\hline
\end{tabular}

Sumber : Hasil analisis. 
Indeks kerentanan di Kecamatan Karangsambung (Tabel 8) lebih melihat dari sudut pandang lingkungan, yang meliputi kerugian ekonomi (peruntukan untuk pertanian, usaha peternakan, dan lahan padi produktif dengan panen $2 \mathrm{x}$ dalam setahun); dan kerugian fisik (bangunan mukim, fasilitas umum dan ibadah, dan jumlah sekolahan). Kerugian ekonomi untuk peruntukkan pertanian untuk Desa Plumbon dan Desa Wadasmalang memiliki nilai tinggi. Kerugian ekonomi dari sisi peternakan yang meliputi usaha sapi potong, sapi perah, kambing, kerbau kuda, ayam petelur dan pedaging desa yang memiliki nilai tinggi berada di Desa Kaligending, Plumbon, Pujotirto, dan Wadasmalang. Kerugian ekonomi dari hasil panen padi Desa Wadasmalang memiliki nilai yang paling tinggi di Kecamatan Karangsambung.

Kerentanan di Kecamatan Karangsambung untuk nilai tertinggi untuk bangunan pemukiman terluas berada di Desa Plumbon dan Wadasmalang, kerentanan fisik berupa fasilitas umum dan ibadah Desa Pujotirto, Wadasmalang, dan Karangsambung memiliki nilai yang tinggi. Kerentanan fisik untuk bangunan sekolahan nilai tertinggi berada di Desa Wadasmalang.

Faktor sosial-masyarakat juga tercermin dalam indeks kapasitas bencana di Kecamatan Karangsambung (Tabel 9). Asumsi dasarnya bahwa kemampuan dari suatu wilayah dalam melakukan pencegahan minimal ketika terjadi suatu bencana. Desa Kedungwaru, Tlepok, dan Totogan merupakan desa dengan jumlah tenaga kesehatan yang minim, sehingga menjadikan menurunkan nilai indeks kapasitas bencana longsor.

Jumlah anggota limnas Desa Plumbon dan Wadasmalang memiliki kesiapan yang paling baik. Indeks kapasitas bencana longsor untuk tenaga pendidik yang memberikan informasi pada sekolah, Desa Karangsambung, Kaligending, Plumbon,
Pujotirto, dan Wadasmalang memiliki nilai paling tinggi.

Hasil penggabungan indeks ancaman bencana longsor (faktor fisik), indeks kerentanan bencana longsor (faktor sosial-masyarakat dan lingkungan), dan indeks kapasitas bencana longsor (faktor sosialmasyarakat) berupa peta risiko bencana longsor Kecamatan Karangsambung seperti pada Gambar 6.

Risiko longsor sangat dipengaruhi oleh kondisi sosial-masyarakat. Daerah dengan kerawanan longsor yang tinggi berdasarkan determinasi faktor fisik tidak selalu memberikan risiko yang tinggi. Peranan sosial-masyarakat dan lingkungan dalam mempengaruhi risiko longsor sangat besar. Fokus dari risiko longsor lebih pada kesiapan masyarakat dalam menghadapi bencana dan kerugian lingkungan dari kejadian longsor.

Potensi ancaman longsor tinggi memiliki penyebaran paling banyak pada Formasi Waturanda, yaitu pada kemiringan tinggi di sekitar igir baik pada sisi dalam maupun luar dari Lembah Antiklin. Desa Totogan yang berada di daerah melang dan Desa Pujotirto yang sebagian besar memiliki litologi berupa Tuff pada kemiringan yang terjal juga sangat berpotensi untuk terjadinya longsor.

Desa Banioro memiliki tingkat resiko yang tinggi, hal ini disebabkan kepadatan penduduk yang tinggi, penduduk cacat tinggi, jumlah tenaga kesehatan sedang, anggota limnas sedikit, dan tenaga pendidik relatif sedikit. Selain itu Desa Banioro yang berada di sebelah utara (igir lembah antiklin) berpotensi untuk terjadinya longsor.

Peta ancaman longsor yang ada di Kecamatan Karangsambung (Gambar 5) menunjukkan bahwa kriteria ancaman longsor rendah sekitar 25,66\%, ancaman longsor sedang sekitar 37,72\%, dan ancaman longsor tinggi sekitar 36,62\%. Risiko longsor di Kecamatan Karangsambung (Gambar 6) menunjukkan bahwa kriteria risiko longsor rendah

Tabel 9. Indeks kapasitas bencana longsor di Kecamatan Karangsambung.

\begin{tabular}{lccccc}
\hline \multicolumn{1}{c}{ Desa } & Tenaga kesehatan & Anggota limnas & Tenaga pendidik & Indeks kapasitas & Kriteria \\
\hline Widoro & 0,50 & 0,75 & 0,5 & 1,75 & Sedang \\
Seling & 1,00 & 0,75 & 0,75 & 2,50 & Tinggi \\
Kedungwaru & 1,50 & 0,75 & 0,75 & 3,00 & Tinggi \\
Pencil & 1,00 & 0,75 & 0,75 & 2,50 & Tinggi \\
Kaligending & 0,50 & 0,5 & 0,25 & 1,25 & Rendah \\
Plumbon & 1,00 & 0,25 & 0,25 & 1,50 & Rendah \\
Pujotirto & 1,00 & 0,50 & 0,25 & 1,75 & Sedang \\
Wadasmalang & 0,50 & 0,25 & 0,25 & 1,00 & Rendah \\
Tlepok & 1,50 & 0,75 & 0,75 & 3,00 & Tinggi \\
Kalisana & 0,50 & 0,75 & 0,75 & 2,00 & Sedang \\
Langse & 1,00 & 0,75 & 0,75 & 2,50 & Sedang \\
Banioro & 1,00 & 0,75 & 0,75 & 2,50 & Sedang \\
Karangsambung & 0,50 & 0,75 & 0,25 & 1,50 & Rendah \\
Totogan & 1,50 & & 0,75 & 3,00 & Tinggi \\
\hline
\end{tabular}

Sumber : Hasil analisis. 


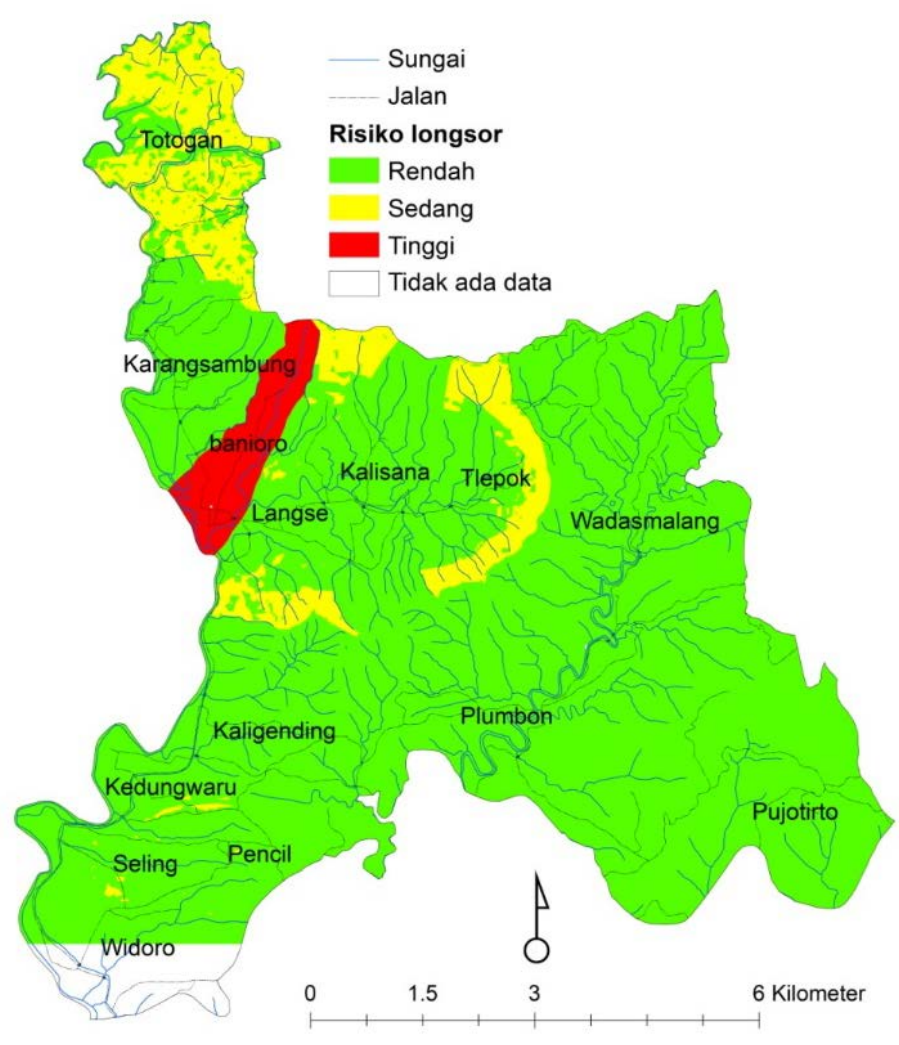

Gambar 6. Peta risiko longsor di Kecamatan Karangsambung.

sekitar 86,94\%, risiko longsor sedang sekitar 9,89\%, dan risiko longsor tinggi sekitar 3,17\%. Perubahan persentase ini didasarkan pada faktor penduduk, ekonomi, sarana-prasara, kesiapan masyarakat, dan dari potensi fisik lahan yang berpotensi terjadinya longsor.

\section{KESIMPULAN}

Pada Kecamatan Karangsambung merupakan daerah sering terjadi longsor. Faktor fisik tersebut dikarenakan topografi berbukit dan litologi yang berbeda-beda. Selain parameter kemiringan yang terjal, batuan pada komplek melang dan formasi waturanda juga menyebabkan kejadian longsor di daerah ini.

Peranan sosial-masyarakat sangat mempengaruhi risiko longsor di Kecamatan Karangsambung. Daerah dengan kerawanan longsor tinggi akan semakin rendah risikonya ketika kerugian yang terjadi rendah. Kondisi sosialmasyarakat yang tinggi dan kesiapan masyarakat baik, serta kerugian lingkungan rendah dapat menurunkan risiko bencana longsor. Dengan demikian daerah dengan kerawanan longsor tinggi tidak selalu menghasilkan resiko yang tinggi pula.

\section{DAFTAR PUSTAKA}

Anonim, 2001. Peta Rupa Bumi Indeonesia. Skala 1:25.000. Lembar Karangsambung. Edisi:12001. Badan Koordinasi Surevai dan Pemetaan Nasional, Cibinong.

Anonim, 2004. Petunjuk Teknis Pengamatan Tanah. Balai Penelitian Tanah. Pusat Penelitian dan Pengembangan Tanah dan Agroklimat, Bogor. Anonim., 2012. Peraturan Kepala Badan Nasional Penanggulangan Bencana No. 02 Tahun 2012 tentang Pedoman Umum Pengkajian Risiko Bencana. Badan Nasional Penanggulangan Bencana (BNPB), Jakarta.

Anonim, 2013. Landsat 8 OLI/TIRS, Scene LC81200652013175LGN00. WRS Path 120WRS Row 065. U.S. Department of the Interior U.S. Geological Survey, Washington.

Anonim, 2014. Kecamatan Karangsambung Dalam Angka. Badan Pusat Statistik, Kebumen.

Asikin, S., Handoyo, A., Busono, H., dan Gafoer, S., 1992. Peta Geologi Lembar Kebumen, Jawa. Pusat Penelitian dan Pengembangan Geologi, Bandung.

Cardinali, M., Reichenbach, P., Guzzetti, F., Ardizzone, F., Antonini, G., Galli, M., Cacciano, M., Castellani, M., and Salvati, P., 2002. A Geomorphological Approach to The Estimation of Landslide Hazards and Risks in Umbria, Central Italy. Natural Hazards and Earth System Sciences, 2:57-72.

Cutter, S.L., Mitchell, J.T., dan Scott, M.S., 2000. Revealing the Vulnerability of People and Places: A Case Study of Georgetown County, South Carolina. Annals of the Association of American Geographers, 90(4):713-737

Eldrandaly, K., 2013. Developing a GIS-Based MCE Site Selection Tool in ArcGIS Using COM Technology. International Arab Journal of Information Technology, 10(3):276-282

Fell R., Ho K.K.S., Lacasse S., dan Leroi E. 2005., A Framework for Landslide Risk Assessment and Management. Proceedings International Conference on Landslide Risk Management. Taylor \& Francis. London. pp 3-25.

Lihawa, F., Patuti, I.M., dan Nurfaika, 2014. Sebaran Aspek Keruangan Tipe Longsoran di Daerah Aliran Sungai Alo Provinsi Gorontalo. Jurnal Manusia dan Lingkungan, 21(3):277285.

Glade, T., 1998. Establishing The Frequency and Magnitude of Landslide-Triggering Rainstorm Events in New Zealand. Environmental Geology, 35(2-3):160-174. 
Glade, T., 2006. Quantitative Landslide Risk Analysis: Between Local Field Monitoring and Spatial Modelling. Int. Assoc. for Mathematical Geology XIth International Congress Université de Liège, Belgium. S0913:1-4.

Guzzetti F., Carrara A., Cardinali M., and Reichenbach, P., 1999. Landslide Hazard Evaluation: an Aid to a Sustainable Development. J. Geomorphology, 31:181216.

Intarawichian, N., dan Dasananda, S., 2010. Analytical Hierarchy Process For Landslide Susceptibility Mapping In Lower Mae Chaem Watershed, Northern Thailand. J. Sci. Technol., 17(3):277-292.

Marjanovic, M., 2009. Landslide Susceptibility Modelling: a Case Study on Fruška Gora Mountain, Serbia. Geomorphologia Slovaca et Bohemica, 9(1):29-42.

Moradi, M., Bazyar, M.H., and Mohammadi, Z., 2012. GIS-Based Landslide Susceptibility Mapping by AHP Method, A Case Study, Dena City, Iran. J. Basic. Appl. Sci. Res., 2(7):6715-6723.

Roberts, N., 2009. Culture and Landslide Risk in The Central Andes of Bolivia and Peru. Studia Universitatis Babeş-Bolyai, Geologia, 54(1):55-59.
Saaty, T.L and Vargas, L.G., 2006. Decision Making With The Analytic Network ProcessEconomic, Political, Social and Technological Applications with Benefits, Opportunities, Costs and Risks. Springer Science Business Media, New York, pp. 11-204.

Santha., S.D and Sreedharan, R.K., 2010. Population Vulnerability and Disaster Risk Reduction: A Situation Analysis Among The Landslide Affected Communities in Kerala, India. Journal of Disaster Risk Studies. 3(1):367380.

Song, Q. H., Liu, D. S., dan Wu, Y. X. 2007. Study on the Acceptable and Tolerable Risk Criteria for Landslide Hazards in the Mainland of China. ISGSR2007 First International Symposium on Geotechnical Safety \& Risk. Shanghai Tongji University, Shanghai. pp. 363-374.

Suharko., 2014. Pencegahan Bencana Lingkungan Hidup Melalui Pendidikan Lingkungan. Jurnal Manusia dan Lingkungan, 21(2):254260.

Suharsono, P., 1988. Identifikasi Bentuk Lahan dan Intepretasi Citra untuk Geomorfologi. Fakultas Geografi, Universitas Gadjah Mada. Yogyakarta.

Timothy, K., 2008. Landslides- Mass Wasting, Soil, and Mineral Hazards. Facts On File, Inc. New York, pp. 15-46. 